\title{
A méhüreg anatómiai rendellenességei habituális vetélőkben
}

\author{
Galamb Ádám dr. ${ }^{1}$ - Pethő Boglárka dr. ${ }^{1}$. Fekete Dávid $^{2}$ \\ Petrányi Győző dr. ${ }^{3}$. Pajor Attila dr. ${ }^{1}$
}

\author{
${ }^{1}$ Semmelweis Egyetem, Általános Orvostudományi Kar, II. Szülészeti és Nőgyógyászati Klinika, Budapest \\ ${ }^{2}$ Egyesített Szent István és Szent László Kórház-Rendelőintézet, Budapest \\ ${ }^{3}$ Magyar Tudományos Akadémia, Budapest
}

\begin{abstract}
Bevezetés: A habituális vetélés a nők 1\%-át érintő rendellenesség, amelynek hátterében genetikai, endokrin, méhűri anatómiai, immunológiai, mikrobiológiai és hematológiai, valamint andrológiai zavarok mutathatók ki mint kockázati tényezők, de az esetek felében ismeretlen ok miatt alakul ki. Célkitüzés: A habituális vetélés kockázati tényezőinek kutatása során a szerzők arra a kérdésre kerestek választ, vajon a magyar lakosságban milyen gyakran fordul elő a méhüreget érintő anatómiai rendellenesség. Módszer: Retrospektív módon dolgozták fel 152 habituális vetélő adatait. Az esetleges méhưri eltérés tisztázására 132 betegben vagy diagnosztikus hiszteroszkópia, vagy a méhüreg 3 dimenziós ultrahangvizsgálata, 16 esetben hysterosalpingographia, 4 esetben hysterosalpingo-sonographia történt. Eredmények: Megállapították, hogy a habituális vetélók 15,8\%-ában méhưri rendellenesség mutatható ki. A rendellenességek közül septum uteri 6,5\%-ban, endometriumpolypus 2,6\%-ban, uterus arcuatus 2\%-ban, uterus bicornis $2 \%$ ban, submucosus myomagöb 1,3\%-ban és méhưri synechiák 1,3\%-ban fordultak elő. Következtetések: A szerzők megfigyelése arra utal, hogy habituális vetélésben szenvedő nőkben a méhüreg morfológiai rendellenessége gyakori. Ilyen esetekben javasolt a méhüreg anatómiai vizsgálata. Orv. Hetil., 2015, 156(27), 1081-1084.
\end{abstract}

Kulcsszavak: habituális vetélés, méhüri rendellenesség

\section{Uterine anomalies in women with recurrent pregnancy loss}

Introduction: One percent of couples trying to have children are affected by recurrent miscarriage. These pregnancy losses have different pathogenetic (genetic, endocrine, anatomic, immunologic, microbiologic, haematologic and andrologic) backgrounds, but recurrent miscarriage remains unexplained in more than half of the affected couples. Aim: To explore risk factors for recurrent pregnancy loss the authors studied the incidence of anatomic disorders of the uterine cavity occur in Hungarian women with recurrent miscarriage. Method: Medical records of 152 patients with recurrent miscarriage were analyzed retrospectively. In order to explore disorders of the uterine cavity hysteroscopy or 3-dimensional sonography in 132 women, hysterosalpingography in 16 and hysterosalpingo-sonography in 4 patients were used. Results: Incidence of anomalies in the uterine cavity was found in women with recurrent miscarriage to be $15.8 \%$. A variety of the uterine anomalies was found including uterine septum in $6.5 \%$, endometrial polyp in $2.6 \%$, arcuate and bicornuate uteri both in $2 \%$ and $2 \%$, submucosal myoma in $1.3 \%$, and intrauterine synechiae in $1.3 \%$. Conclusions: These findings suggest that morphologic disorder of the uterine cavity is frequent in Hungarian women with recurrent miscarriage. Therefore, assessment of the uterine anatomy is recommended in such patients.

Keywords: recurrent miscarriage, uterine malformations

Galamb, Á., Pethö, B., Fekete, D., Petrányi, Gy., Pajor, A. [Uterine anomalies in women with recurrent pregnancy loss]. Orv. Hetil., 2015, 156(27), 1081-1084.

(Beérkezett: 2015. február 9.; elfogadva: 2015. április 18.) 
A habituális vetélés a klasszikus nemzetközi definíció szerint legalább 3 vagy több, a 20. terhességi hét előtt bekövetkezett, egymást követő vetélést jelent. Amennyiben a páciens 35 év felett van, 2 egymást követő vetélés is ide tartozik [1]. Nem tartozik ide viszont a mola terhesség, a méhen kívüli terhesség és az úgynevezett biokémiai terhesség. A spontán fogant terhességek 15\%-a az I. trimeszterben vetéléssel végződik, és ez a gyakoriság az anyai életkorral arányosan növekszik [2]. Fentiek alapján a véletlen, 2 egymást követő vetélés esélye 2,25\%, a véletlen, 3 egymást követő vetélés esélye $0,3 \%$ lenne. Ezzel szemben a 3 egymást követő vetélés (habituális vetélők) aránya 0,4 és 1\% közé esik. Ennek oka, hogy egyes hormonális, anyagcsere-, genetikai, immunológiai, anatómiai és egyéb rendellenességek rendre a terhesség korai megszakadásának kockázati tényezői (1. táblázat) [3, $4,5]$. A habituális vetélók 40\%-ában azonban az eddig ismert kockázati tényezők egyike sem fedhető fel, más források szerint az ismeretlen etiológia aránya az 50\%-ot is eléri [6].

Egyes tanulmányok szerint a populáció 7\%-ában fordul elő méhüri rendellenesség, míg a habituális vetélők esetén ez a szám 10-15\% körül van [7, 8, 9]. Ezzel összhangban áll az, hogy a fejlődési rendellenességből fakadó strukturális eltérések (Müller-cső-anomáliák) arányát 8-10\%-ra becsülik [10]. Más megfigyelések szerint a habituális vetélők között a méhưri rendellenességek aránya csupán 2,2\% [11], illetve 6,9\% [12].

Mivel hazai adatok nem állnak rendelkezésre, tanulmányunkban arra a kérdésre kerestük a választ, milyen gyakori lehet a méhüri rendellenesség a hazai habituális vetélőkben.

\section{Módszer}

Retrospektív módon dolgoztuk fel 152 habituális vetélő adatait. A páciensek a hazánkban 2012 óta múködő Habituális Vetélés Bizottság által véleményezett, az ország különböző ellátóiból küldött betegek köréből kerültek ki. Habituális vetélőknek tekintettük a bevezetőben részletezett definíció szerinti pácienseket. Az esetleges méhúri eltérés tisztázására 132 esetben diagnosztikus hiszteroszkópia vagy az uterus cavum és kismedence 3D ultrahangvizsgálata történt, 16 esetben hysterosalpingographiát, 4 esetben hysterosalpingo-sonographiát végeztek.

\section{Eredmények}

Méhűri anatómiai eltérés 152 páciensből 24 személynél fordult elő $(15,8 \%)$. A 24 esetből septum uteri 10 esetben $(6,5 \%)$, endometriumpolypus 4 esetben $(2,6 \%)$, uterus arcuatus 3 esetben (2\%), uterus bicornis 3 esetben (2\%), submucosus myomagöb 2 esetben (1,3\%) és méhûri synechia 2 esetben (1,3\%) igazolódott (2. táblázat).

\section{Megbeszélés}

A szakirodalomban megjelent egyik, legtöbb esetet feldolgozó tanulmányban a 4500 habituális vetélőnek a $13 \%$-ában fordult elő méhüri eltérés, ebből uterus septus $35 \%$, uterus bicornis $26 \%$, uterus arcuatus $18 \%$, uterus unicornis rudimenter szarvval 10\%, uterus duplex $8 \%$, egyéb 3\% [13] volt. A hazai páciensekben, ha eltekintünk a méhnyálkahártya-polipoktól, 13,1\%-ban mutattunk ki méhüreget érintő fejlődési rendellenességet.

Kimutatták, hogy uterus septum esetén a terhességek 60-65\%-a megszakad [9, 14]. Mások szerint az uterus septum jelenléte 25,5\%-ban korai és 6,2\%-ban késői vetéléssel jár együtt [15]. A teljes méhüreget átérő septumok esetében a spontán vetélés valószínűsége 21-44\% [16]. A septum hossza fordított arányban áll a terhesség kedvező kimenetelének esélyével [17]. A zavar oka a septum kedvezőtlen vérellátása, illetve az implantációs nehézség lehet [14]. A méhüregi septum diagnózisának legbiztosabb módja a laparoszkópia és hiszteroszkópia kombinációja, amely egyben az operatív megoldás lehe-

1. táblázat |A habituális vetélés hátterében kimutatott kockázati tényezők $[3,4,5]$

\begin{tabular}{llll}
\hline Kockázati tényezők & $\begin{array}{l}\text { Kutteh, et al. } \\
(\%)[3]\end{array}$ & $\begin{array}{l}\text { Ford, et al. (\%) } \\
{[4]}\end{array}$ & $\begin{array}{l}\text { Sugiura- } \\
\text { Ogasawara, } \\
\text { et al. (\%) [5] }\end{array}$ \\
\hline Immunológiai & 25 & 20 & 10 \\
Méhüregi eltérés & 22 & $10-15$ & 3 \\
Endokrinológiai & 20 & $17-20$ & 12 \\
Mikrobiológiai & 6 & $0,5-5$ & 0 \\
Genetikai & 3 & $2-5$ & 6 \\
Ismeretlen & 40 & $40-50$ & 69
\end{tabular}

2. táblázat |A méhưri rendellenességek előfordulása 152 habituális vetélóben

\begin{tabular}{|c|c|c|c|c|c|}
\hline \multirow{2}{*}{$\begin{array}{l}\text { Méhüri } \\
\text { eltérés }\end{array}$} & \multicolumn{5}{|c|}{ Diagnózis módja } \\
\hline & HSG & HSSG & $\begin{array}{l}\text { 3D } \\
\text { ultrahang- } \\
\text { vizsgálat }\end{array}$ & $\begin{array}{l}\text { Hisztero- } \\
\text { szkópia, } \\
\text { laparoszkópia }\end{array}$ & Összesen \\
\hline Septum uteri & $(3)^{*}$ & - & - & (7) $10 *$ & 10 \\
\hline $\begin{array}{l}\text { Polypus } \\
\text { endometrii }\end{array}$ & - & 1 & - & 3 & 4 \\
\hline $\begin{array}{l}\text { Uterus } \\
\text { arcuatus }\end{array}$ & - & - & 2 & 1 & 3 \\
\hline $\begin{array}{l}\text { Submucosus } \\
\text { myomagöb }\end{array}$ & - & - & 1 & 1 & 2 \\
\hline $\begin{array}{l}\text { Uterus } \\
\text { bicornis }\end{array}$ & - & - & - & 3 & 3 \\
\hline $\begin{array}{l}\text { Uterinalis } \\
\text { synechia }\end{array}$ & - & - & - & 2 & 2 \\
\hline
\end{tabular}

HSG = hysterosalpingographia; HSSG: hysterosalpingo-sonographia. *A rendellenességet 3 esetben HSG vetette fel, a végső diagnózist azonban a hiszteroszkópia adta. 
tőségét is megteremti. A sövény kiirtása után a sikeres terhesség aránya megnő [14], az élveszülés aránya akár az $54 \%$-ot is elérheti [18]. Saját anyagunkban septum uteri diagnózisát mind a 10 esetben hiszteroszkópia segítségével állítottuk fel. Valamennyi esetünkben a sövény mútéti megoldása megtörtént. A sövény kiirtása után 4 esetben vetélés következett be, 4 esetben pedig a páciens sikeres terhességet hordott ki. Mindezek alapján úgy látszik, hogy a sövény kiirtása után az esetek felében sikeres lesz a következő terhesség.

Uterus arcuatus 3 esetben, a hazai habituális vetélók $2 \%$-ában fordult elő. 2 esetben 3D ultrahangvizsgálat, 1 esetben laparoszkópia segítségével diagnosztizálták. Mütéti megoldás 1 esetben történt (metroplastica), ami után terhesség egyelőre még nem jött létre. Megfigyelések szerint arcuált méh esetén korai vetélés 13-45\%-ban következik be $[15,19]$.

Uterus bicornis 3 esetben (2\%) fordult elő. A diagnózist korai spontán vetéléseket követően állították fel, esetükben mütét nem történt. Az egyik esetben a páciens a diagnózis felállítása után sikeres ikerterhességet viselt ki.

$\mathrm{Az}$ endometriumpolypus és a habituális vetélés közötti összefüggés még nem kellően tisztázott. Valószínúleg a polip környezetében megváltozott lokális immunfunkciók a felelősek az ismételt vetélésekért [20]. Az in vitro fertilizáció programban részt vevő páciensek körében 6-8\%-ban találnak endometriumpolypust hiszteroszkóp segítségével [21]. A polip kiirtását indokoltnak tartják [22], mivel egy 204 esetet összegyűjtő tanulmány a teherbe esés arányának jelentős növekedéséről számol be azoknál, akiknél hiszteroszkópos polypectomia történt $[23,24]$. Az ismételt vetélésekkel azonban az endometriumpolypus nem hozható egyértelmú összefüggésbe, ugyanis a habituális vetélőkben az előfordulási aránya nem nagyobb, mint az átlagpopulációban megfigyelt előfordulás $[25,26]$. A méhnyálkahártya polipja a hazai habituális vetélők 3,5\%-ában fordul elő. Diagnózisa 3 esetben hiszteroszkóppal, l esetben hysterosalpingo-sonographiával történt. 4 esetből 3 alkalommal történt mútéti megoldás. A polip kiirtása után 1 esetben újabb vetélés zajlott le, 2 esetben a mütét után terhesség még nem következett be.

A submucosus elhelyezkedésű myomagöbök, nemzetközi adatok szerint, fontos szerepet játszhatnak a sikertelen terhességek etiológiájában az implantáció megakadályozásával, a fokozott citokintermeléssel, valamint a myomát fedő decidua befogadóképességének csökkentésével [27]. Operatív megoldásuk után a sikeres terhességek aránya jelentősen megnő: 69\%-ról 25\%-ra csökken a korai vetélések aránya [28]. Submucosus myomagöb a hazai habituális vetélők $1,7 \%$-ában fordult elő. 1 esetben ultrahangvizsgálat, l esetben hiszteroszkópia révén ismerték fel. Mütétet az egyik esetben végeztek, amelyet követően újabb vetélés jött létre.

Intrauterin synechia 2 esetben fordult elő, egyik esetben 2 spontán vetélést, másik esetben 2 spontán vetélést és egy császármetszést követően diagnosztizálták. Müté- ti megoldásuk után teherbe esés eddig nem következett be.

A méhüreg vizsgálati módszerei közül a standardnak a hiszteroszkópia tekinthető, és egyben az operatív megoldás lehetőségét is nyújtja. Még teljesebb képet kapunk a laparoszkópia-hiszteroszkópia kombinációjával, mivel így a transmuralis myomagöbökről vagy a Müller-csőrendellenességekról is információt nyerhetünk. Hazánkban nem terjedt el ilyen célra, de külföldön a diagnosztikus mútétek kiváltására egyre szélesebb körben használják az MRI-t, mivel a nem invazív eljárások közül a legnagyobb szenzitivitással rendelkezik és költséghatékonyabb eljárás, mint a mütétes megoldás [29]. Az utóbbi időben egyre több szerző felveti a 3D ultrahangvizsgálat hasznosságát, mivel pontossága megfelelő és a 2D ultrahangfelvételeknél jóval megbízhatóbb a méhűri eltérések kimutatásában, illetve az MRI-hez hasonlóan az uterus külső felszínének megítélésére is alkalmas, de annál egyszerúbb és olcsóbb eljárás [30, 31]. Diagnosztikai célból alkalmazható még a hysterosalpingographia és a hysterosalpingo-sonographia is. Szenzitivitásuk azonban elmarad a korábban részletezett eljárásokétól. A hysterosalpingo-sonographia pontosabb a hysterosalpingographiánál és több információt ad [32, 33], valamint az uterus bicornis/septus kérdése is jobban megítélhető $[14,34]$.

Anyagi támogatás: A közlemény megírása, illetve a kapcsolódó kutatómunka anyagi támogatásban nem részesült.

Szerzői munkamegosztás: G. Á., P. B., P. Gy., P. A.: Hipotézisek kidolgozása. G. Á., P. B., P. Gy., F. D., P. A.: A vizsgálat lefolytatása. G. Á., P. A., F. D.: Statisztikai elemzések. G. Á., P. A: A kézirat megszövegezése. A cikk végleges változatát valamennyi szerző elolvasta és jóváhagyta.

Érdekeltségek: A szerzőknek nincsenek érdekeltségeik.

\section{Irodalom}

[1] Practice Committee of the American Society for Reproductive Medicine: Definitions of infertility and recurrent pregnancy loss. Fertil. Steril., 2008, 89(6), 1603.

[2] Nybo Andersen, A. M., Woblfabrt, J., Christens, P., et al.: Maternal age and fetal loss: population based register linkage study. BMJ, 2000, 320(7251), 1708-1712.

[3] Kutteh, W. H., Carney, J. L.: Etiologic factors in women with a history of recurrent pregnancy loss. Obstet. Gynecol., 1999, 93, $42 \mathrm{~S}$.

[4] Ford, H. B., Schust, D. J.: Recurrent pregnancy loss: etiology, diagnosis, and therapy. Rev. Obstet. Gynecol., 2009, 2(2), 76-83.

[5] Sugiura-Ogasawara, M., Ozaki, $\Upsilon$. Suzumori, N.: Management of recurrent miscarriage. J. Obstet. Gynaecol. Res., 2014, 40(5), 1174-1179.

[6] Abramson, J., Stagnaro-Green, A.: Thyroid antibodies and fetal loss: an evolving story. Thyroid, 2001, 11(1), 57-63. 
[7] Harger, J. H., Archer, D. F., Marchese, S. G., et al.: Etiology of recurrent pregnancy losses and outcome of subsequent pregnancies. Obstet. Gynecol., 1983, 62(5), 574-581.

[8] Acién, P., Acién, M., Sánchez-Ferrer, M.: Complex malformations of the female genital tract. New types and revision of classification. Hum. Reprod., 2004, 19(10), 2377-2384.

[9] Devi Wold, A. S., Pham, N., Arici, A.: Anatomic factors in recurrent pregnancy loss. Semin. Reprod. Med., 2006, 24(1), 25-32.

[10] Propst, A. M., Hill, J. A. 3rd: Anatomic factors associated with recurrent pregnancy loss. Semin. Reprod. Med., 2000, 18(4), 341-350.

[11] Diejomaoh, M. F., Al-Azemi, M., Jirous, J., et al.: The aetiology and pattern of recurrent pregnancy loss. J. Obstet. Gynaecol., 2002, 22(1), 62-67.

[12] Sugiura-Ogasawara, M., Ozaki, Y., Katano, K., et al.: Uterine anomaly and recurrent pregnancy loss. Semin. Reprod. Med., 2011, 29(6), 514-521.

[13] Grimbizis, G. F., Camus, M., Tarlatzis, B. C., et al.: Clinical implications of uterine malformations and hysteroscopic treatment results. Hum. Reprod. Update, 2001, 7(2), 161-174.

[14] Homer, H. A., Li, T. C., Cooke, I. D.: The septate uterus: a review of management and reproductive outcome. Fertil. Steril., 2000, 73(1), 1-14.

[15] Raga, F., Bauset, C., Remohi, J., et al.: Reproductive impact of congenital Müllerian anomalies. Hum. Reprod., 1997, 12(10), 2277-2281

[16] Heinonen, P. K.: Complete septate uterus with longitudinal vaginal septum. Fertil. Steril., 2006, 85(3), 700-705

[17] Buttram, V. C. Jr., Gibbons, W. E.: Müllerian anomalies: a proposed classification (An analysis of 144 cases). Fertil. Steril., $1979,32(1), 40-46$.

[18] Valle, R. F., Ekpo, G. E.: Hysteroscopic metroplasty for the septate uterus: review and meta-analysis. J. Minim. Invasive Gynecol., 2013, 20(1), 22-42.

[19] Acién, P.: Reproductive performance of women with uterine malformations. Hum. Reprod., 1993, 8(1), 122-126.

[20] Kitaya, K. 1., Tada, Y, Taguchi, S., et al.: Local mononuclear cell infiltrates in infertile patients with endometrial macropolyps versus micropolyps. Hum. Reprod., 2012, 27(12), 3474-3480.

[21] Fatemi, H. M., Kasius, J. C., Timmermans, A., et al.: Prevalence of unsuspected uterine cavity abnormalities diagnosed by office hysteroscopy prior to in vitro fertilization. Hum. Reprod., 2010, 25, 1959-1965.

[22] Lieng, M., Istre, O., Qvigstad, E.: Treatment of endometrial polyps: a systematic review. Acta Obstet. Gynecol. Scand., 2010, 89, 992-1002.
[23] Pérez-Medina, T., Bajo-Arenas, J., Salazar, F., et al.: Endometrial polyps and their implication in the pregnancy rates of patients undergoing intrauterine insemination: a prospective, randomized study. Hum. Reprod., 2005, 20, 1632-1635.

[24] Bosteels, J., Kasius, J., Weyers, S., et al.: Hysteroscopy for treating subfertility associated with suspected major uterine cavity abnormalities. Cochrane Database Syst. Rev., 2013, 1, CD009461.

[25] Cogendez, E., Dolgun, Z. N., Sanverdi, I., et al.: Post-abortion hysteroscopy: a method for early diagnosis of congenital and acquired intrauterine causes of abortions. Eur. J. Obstet. Gynecol. Reprod. Biol., 2011, 156(1), 101-104.

[26] Souza, C. A., Schmitz, C., Genro, V. K., et al.: Office hysteroscopy study in consecutive miscarriage patients. Rev. Assoc. Med. Bras., 2011, 57, 397-401.

[27] Simpson, J. L.: Causes of fetal wastage. Clin. Obstet. Gynecol., $2007,50,10-30$.

[28] Marchionni, M., Fambrini, M., Zambelli, V., et al.: Reproductive performance before and after abdominal myomectomy: a retrospective analysis. Fertil. Steril., 2004, 82(1), 154-159.

[29] Pellerito, J. S., McCarthy, S. M., Doyle, M. B., et al.: Diagnosis of uterine anomalies: relative accuracy of MR imaging, endovaginal sonography, and hysterosalpingography. Radiology, 1992, 183, 795-800.

[30] Caliskan, E., Ozkan, S., Cakiroglu, ., et al.: Diagnostic accuracy of real-time 3D sonography in the diagnosis of congenital Mullerian anomalies in high-risk patients with respect to the phase of the menstrual cycle. J. Clin. Ultrasound, 2010, 38, 123-127.

[31] Bermejo, C., Martínez Ten, P., Cantarero, R., et al.: Three-dimensional ultrasound in the diagnosis of Müllerian duct anomalies and concordance with magnetic resonance imaging. Ultrasound Obstet. Gynecol., 2010, 35, 593-601.

[32] Goldberg, J. M., Falcone, T., Attaran, M.: Sonohysterographic evaluation of uterine abnormalities noted on hysterosalpingography. Hum. Reprod., 1997, 12, 2151-2153.

[33] Soares, S. R., Barbosa dos Reis, M. M., Camargos, A. F.: Diagnostic accuracy of sonohysterography, transvaginal sonography, and hysterosalpingography in patients with uterine cavity diseases. Fertil. Steril., 2000, 73, 406-411.

[34] Renter, K. L., Daly, D. C., Cohen, S. M.: Septate versus bicornuate uteri: errors in imaging diagnosis. Radiology, 1989, 172, 749-752.

(Galamb Ádám dr., Budapest, Üllői út 78/A, 1082 e-mail: galamb.adam@gmail.com) 